\title{
PENGARUH FAKTOR INDIVIDUAL, SITUASIONAL, DAN ORGANISASIONAL TERHADAP NIAT MELAKUKAN WHISTLE-BLOWING PADA AKUNTAN DI BATAM (STUDI KASUS POLITEKNIK NEGERI BATAM)
}

\author{
Mega Mayasari ${ }^{1}$, Rusda Irawati ${ }^{2}$ dan Adi Irawan ${ }^{3}$ \\ ${ }^{1}$ Politeknik Negeri Batam Program Studi Akuntansi \\ ${ }^{2}$ Politeknik Negeri Batam Program Studi Administrasi Bisnis Terapan \\ ${ }^{3}$ Politeknik Negeri Batam Program Studi Akuntansi Manajerial \\ Jl. Ahmad Yani, Batam Center, Batam 29461, Indonesia \\ E-mail:mega@polibatam.ac.id.ac.id \\ ira@polibatam.ac.id \\ adiirawan@polibatam.ac.id
}

\begin{abstract}
Abstrak
Penelitian ini bertujuan menguji persepsi karyawan Bagian Akuntansi di Batam terkait dengan pengaruh faktor individual, situasional dan organisasional terhadap niat untuk melakukan whistle-blowing internal dan eksternal. Teknik pengumpulan data yang digunakan adalah Purposive sampling. Metode yang digunakan untuk mendapatkan data penelitian adalah melalui survei dengan kuesioner. Kuesioner disebarkan kepada Mahasiswa kelas karyawan Program Studi Akuntansi dan Program Studi Akuntansi Manajerial, Politeknik Negeri Batam yang bekerja pada Bagian Akuntansi. Kuesioner yang sudah terkumpul dianalisis menggunakan PLS-SEM. Hasil penelitian ini menunjukkan bahwa faktor yang mempengaruhi niat karyawan Bagian Akuntansi untuk melakukan whistle-blowing internal adalah sikap terhadap whistle-blowing, kontrol perilaku persepsian dan komitmen organisasi. Sedangkan faktor yang mempengaruhi niat karyawan Bagian Akuntansi untuk melakukan whistle-blowing eksternal adalah norma subjektif.
\end{abstract}

Kata kunci: Whistle-Blowing intention internal dan eksternal, faktor individual, faktor situasional, faktor organisasional, Theory of Planned Behaviour

\begin{abstract}
This study aims to examine the perceptions of employees of the Accounting Section in Batam related with the influence of individual, situational and organizational factors on the intention to doing internal and external whistle-blowing. The data collection technique used is Purposive sampling. The method used to obtain research data is through a survey with questionnaires. Questionnaires distributed to Student class employees Accounting Study Program and Management Accounting Program Managerial, Batam State Polytechnic working in Accounting Section. The collected questionnaires were analyzed using PLS-SEM. The results of this study indicate that the factors that affect the intentions of employees of Accounting Division to conduct internal whistle-blowing are attitudes toward whistle-blowing, perceptual behavior control and organizational commitment. While the factors that affect the intentions of employees of Accounting Section to conduct external whistle-blowing is the subjective norm.
\end{abstract}

Key words: Whistleblowing internal and external intention, individual factors, situational factors, organizational factors, Theory of Planned Behavior

\section{Pendahuluan}

Berdasarkan hasil survey di tahun 2015 Indonesia berada pada urutan 88 dari 167 negara terkait dengan tindakan korupsi pada sektor publik (www.transparency.org). Korupsi tidak hanya ditemukan pada organisasi sektor publik, pada organisasi swasta juga pernah ditemukan terjadinya 
tindakan kecurangan atau tindakan tidak etis. Pada tahun 2016 terjadi kasus kecurangan di PT EMR Indonesia (Batam), berupa penggelapan dana penjualan besi scrab sebesar tiga puluh enam miliar rupiah, terdeteksinya kecurangan tersebut karena ketidak seimbangan laporan keuangan perusahaan (Haluankepri.com). Melihat semakin maraknya tindakan kecurangan, membuat melaporkan tindakan tidak etis itu menjadi sesuatu yang penting.

Sebutan Batam sebagai kota industri, tidak lepas dari banyaknya perusahaan yang berdiri disana. Hal itu menyebabkan dibutuhkannya banyak tenaga kerja. Khususnya tenaga kerja Bagian Akuntansi untuk mengelola keuangan perusahaan. Karyawan yang bekerja pada Bagian Akuntansi perusahaan sudah tentu tahu dengan pasti bagaimana perusahaan itu berjalan. Karena bagian akuntansilah yang melakukan identifikasi bukti transaksi, penjurnalan sampai dengan proses penyusunan laporan keuangan. Alleyne et. al $(2013)^{3}$, menyatakan bahwa karyawan bagian akuntansi peduli dengan kode etik perusahaannya. Sehingga lebih memungkinkan untuk memberikan pengaduan terkait dengan tindakan tidak etis. Penelitian ini menggunakan sampel penelitian karyawan akuntansi pada perusahaan di Batam.

Berdasarkan uraian pada bagian latar belakang, maka tim peneliti tertarik untuk meneliti Bagaimana pengaruh faktor individual, situasional, dan organisasional terhadap niat melakukan whistle-blowing. Tujuan dari penelitian ini secara umum adalah untuk menguji persepsi akuntan berkaitan dengan niat melakukan whistle-blowing. Niat merupakan pendorong penting terjadinya suatu perilaku. Adapun manfaat yang diharapkan tim peneliti dari penelitian ini adalah dapat menambah pemahaman literatur yang berhubungan dengan Whistle-Blowing. Khususnya faktor-faktor yang mempengaruhi niat karyawan Bagian Akuntansi untuk melakukan Whistle-Blowing. Selain itu tim peneliti juga berharap hasil penelitian ini dapat menjadi masukan bagi perusahaan untuk mengembangkan kebijakan dan prosedur Whistle-Blowing, yang dapat digunakan untuk mendeteksi terjadinya kecurangan sehingga tata kelola perusahaan yang baik dapat tercipta. Tim peneliti membatasi niat melakukan whistle-blowing pada penelitian ini adalah niat melakukan whistle-blowing internal dan eksternal.

\section{Kerangka Teori}

\subsection{Teori dan Penelitian Terdahulu}

Teori yang digunakan dalam penelitian ini adalah TPB (Theory of Planned Behaviour), TPB merupakan teori yang diusulkan oleh Ajzen. Menurut Hartono (2008) ${ }^{4}$ TPB menunjukkan bahwa tindakan manusia ditunjukkan oleh tiga macam kepercayaan. Kepercayaan perilaku yaitu kepercayaan tentang kemungkinan terjadinya perilaku. Kepercayaan normatif yaitu kepercayaan normatif tentang kepercayaan ekspektasi-ekspektasi normatif dari orang-orang lain dan motivasi untuk menyetujui ekspektasi-ekspektasi tersebut. Kepercayaan kontrol kepercayaan tentang keberadaan faktor-faktor yang akan memfasilitasi atau merintangi kinerja dari perilaku dan kekuatan persepsian dari faktor-faktor tersebut. Semakin kuat niat maka semakin berhasil suatu perilaku. TPB mengembangkan TRA dengan menambahkan sebuah konstruk kontrol perilaku persepsian yang akan dipersepsikan dan mempengaruhi niat dan perilaku (Hartono, 2008).

Whistle-blowing adalah kebijakan yang membutuhkan karyawan untuk melaporkan berbagai pelanggaran yang mereka temukan di dalam perusahaan (David, 2011) $)^{5}$. Mahkamah Agung melalui Surat Edaran Mahkamah RI Nomor 4 Tahun 2011 menerjemahkan whistle blower sebagai pelapor tindak pidana yang mengetahui dan melaporkan tindak pidana tertentu dan bukan bagian dari pelaku kejahatan yang dilaporkannya.

Luthans $(2006)^{6}$ menyatakan Komitmen organisasi adalah suatu keadaan di mana seseorang karyawan memihak organisasi tertentu serta tujuan-tujuan dan keinginannya untuk mempertahankan keanggotaan dalam organisasi yang diikutinya. Pengertian lain menurut Luthans (2006) komitmen organisasi adalah keinginan kuat untuk tetap sebagai anggota, berusaha sesuai keinginan dan penerimaan nilai serta tujuan dari organisasi yang dianutnya. Menurut Robbins didefinisikan bahwa keterlibatan pekerjaaan yang tinggi berarti memihak pada pekerjaan tertentu seseorang individu, sementara komitmen organisasional yang tinggi berarti memihak organisasi yang merekrut individu tersebut. Komitmen organisasi dapat disimpulkan sebagai refleksi loyalitas atau kesetiaan karyawan pada organisasi dan proses berkelanjutan dimana seorang anggota organisasi mengekspresikan perhatianya untuk keberhasilan dan kemajuan organisasi.

Etika bisnis merupakan studi yang dikhususkan mengenai moral yang benar dan salah. Studi ini berkonsentrasi pada standar moral sebagaimana diterapkan dalam kebijakan, institusi, dan perilaku bisnis. Etika bisnis merupakan standar formal dan bagaimana standar itu diterapkan ke dalam system. Etika bisnis adalah cara-cara untuk melakukan kegiatan bisnis, yang mencakup seluruh aspek yang berkaitan dengan individu, perusahaan, industri dan juga masyarakat.

Perusahaan meyakini prinsip bisnis yang baik adalah bisnis yang beretika, yakni bisnis dengan kinerja unggul dan berkesinambungan yang dijalankan dengan mentaati kaidah-kaidah etika sejalan dengan hukum 
dan peraturan yang berlaku. Etika Bisnis dapat menjadi standar dan pedoman bagi seluruh karyawan termasuk manajemen dan menjadikannya sebagai pedoman untuk melaksanakan pekerjaan sehari-hari dengan dilandasi moral yang luhur, jujur, transparan dan sikap yang profesional.

Penelitian terdahulu yang menjadi dasar penelitian ini adalah Alleyne et.al (2013) dan Winardi (2013) ${ }^{7}$. Alleyne et.al (2013) meneliti tentang faktor-faktor yang diprediksi dapat mempengaruhi niat untuk melakukan whistle-blowing internal dan eksternal. Penelitian Winardi (2013) menguji faktor situasional dan faktor individual yang mempengaruhi niat pegawai negeri sipil untuk melakukan whistle-blowing. Variabel faktor situasional menggunakan variabel keseriusan kesalahan (seriouness of wrongdoing), status pembuat kesalahan (status of wrongdoer), personal cost of reporting, dan faktor individual diwakili oleh sikap terhadap whistle-blowing (attitude towards whistle-blowing), norma subjektif (subjective norm), pengendalian perilaku persepsian (perceived behavioural control). Alleyne $(2016)^{8}$ meneliti kembali pengaruh komitmen organisasi dan nilai etika perusahaan terhadap internal dan eksternal whistle-blowing, dengan menggunakan sampel 236 non publik akuntan. Hasil dari penelitian tersebut menyebutkan bahwa komitmen organisasi dan nilai etika perusahaan secara signifikan mempengaruhi niat melakukan whistle-blowing internal dan eksternal.

\subsection{Hipotesis Penelitian}

\section{Faktor individual}

Sikap terhadap whistle-blowing (Attitude toward whistle-blowing)

H1a: Sikap terhadap whistle-blowing, berpengaruh terhadap niat untuk melakukan whistle-blowing internal

H1b: Sikap terhadap whistle-blowing, berpengaruh terhadap niat untuk melakukan whistle-blowing eksternal

\section{Norma subjektif (Subjective norm)}

H2a: Norma subjektif berpengaruh terhadap niat untuk melakukan whistle-blowing internal

$\mathrm{H} 2 \mathrm{~b}$ : Norma subjektif berpengaruh terhadap niat untuk melakukan whistle-blowing eksternal

Kontrol perilaku persepsian (Perceived Behavioural control)

H3a: Kontrol perilaku persepsian berpengaruh terhadap niat untuk melakukan whistle-blowing internal
H3b: Kontrol perilaku persepsian berpengaruh terhadap niat untuk melakukan whistle-blowing eksternal

\section{Faktor Situasional}

Keseriusan kesalahan (Seriousness of wrongdoing)

H4a: Keseriusan kesalahan, berpengaruh terhadap niat untuk melakukan whistle-blowing internal

H4b: Keseriusan kesalahan, berpengaruh terhadap niat untuk melakukan whistle-blowing eksternal

\section{Status pelaku kesalahan (Status of wrongdoer)}

H5a:.Ketidak sesuaian yang dilakukan oleh atasan berpengaruh terhadap niat untuk melakukan whistle-blowing internal

H5b:.Ketidak sesuaian yang dilakukan oleh atasan berpengaruh terhadap niat untuk melakukan whistle-blowing eksternal

\section{Faktor organisasional}

Komitmen organisasi

H6a: Komitmen organisasi berpengaruh terhadap niat untuk melakukan whistle-blowing internal

H6b: Komitmen organisasi berpengaruh terhadap niat untuk melakukan whistle-blowing eksternal

\section{Etika Bisnis Perusahaan (Corporate Ethical)}

H7a: Etika bisnis perusahaan berpengaruh terhadap niat untuk melakukan whistle-blowing internal

H7b: Etika bisnis perusahaan berpengaruh terhadap niat untuk melakukan whistle-blowing eksternal

\section{Metode Penelitian}

\subsection{Populasi dan Sampel}

Data dalam penelitian ini menggunakan data primer. Data diperoleh melalui penyebaran kuesioner secara langsung kepada objek penelitian yaitu, mahasiswa kelas karyawan Program studi Akuntansi dan Akuntansi Manajerial Politeknik Negeri Batam yang bekerja di Bagian Akuntansi/ Akuntan pada perusahaan di Batam. Sampel penelitian adalah mahasiswa kelas karyawan program studi Akuntansi dan Akuntansi Manajerial Politeknik Negeri Batam yang bekerja pada Bagian Akuntans/sebagai Akuntan di Batam. Sampel penelitian diambil berdasarkan metode purposive sampling dengan kriteria mahasiswa kelas karyawan program studi Akuntansi dan Akuntansi Manajerial Politeknik Negeri Batam yang bekerja pada Bagian Akuntansi/ sebagai Akuntan di Batam. 


\subsection{Instrumen Penelitian}

Instrumen penelitian yang digunakan adalah kuesioner dan teknik pengumpulan data yang digunakan adalah teknik survei dengan kuesioner. Kuesioner penelitian diadaptasi dari Winardi et.al (2013), Alleyne et.al (2013). Kuesioner terdiri dari dua bagian: bagian pertama berisi pertanyaan inti penelitian dan bagian kedua berisi data diri responden secara umum. Responden tidak diminta untuk mengisi data identitas diri secara khusus seperti nama, sehingga diharapkan responden dapat dengan leluasa mengisi kuesioner tersebut.

\subsection{Metode Analisis Data}

Data yang berasal dari kuesioner ditabulasikan dan kemudian diolah menggunakan software pengolahan data Smart-PLS versi 3. Setelah dilakukan rekapitulasi kuesioner yang telah diisi oleh responden maka langkah selanjutnya adalah melakukan pengolahan data. Alat bantu yang digunakan untuk melakukan proses pengolahan data adalah Smart-PLS versi 3 . Analisis data awal menggunakan metode analisis statistik deskriptif. Alat analisis data yang digunakan untuk pengujian hipotesis adalah PLS-SEM, Alasan penggunaan alat analisis ini sesuai dengan Gudono dan Latan $(2013)^{9}$ yang menyatakan bahwa PLS-SEM digunakan jika tujuan penelitian untuk mengembangkan teori atau membangun teori (orientasinya adalah prediksi), memiliki model penelitian dengan kompleksitas besar dengan banyak konstruk dan banyak indikator (jika terdapat konstruk formatif dalam model penelitian maka gunakan PLS-SEM (Sholihin, 2013) ${ }^{10}$, tidak mensyaratkan data terdistribusi normal dan estimasi parameter dapat langsung dilakukan tanpa persyaratan kriteria goodness of fit, pengujian signifikansi harus melalui bootstrap/jackknife. Sholihin (2013) menyatakan bahwa PLS-SEM merupakan sebuah pendekatan pemodelan kausal yang bertujuan memaksimumkan variansi dari variabel laten kriterion yang dapat dijelaskan oleh variabel laten prediktor.

\section{Hasil}

Dari 361 kuesioner yang disebarkan, terdapat 15 kuesioner yang tidak kembali, dan 94 kuesioner tidak lengkap. Kuesioner yang kembali dan lengkap berjumlah 252 kuesioner. Dari 252 kuesioner tersebut, terdapat 125 kuesioner yang responden penelitiannya adalah akuntansi dan 127 kuesioner yang respondennya non akuntansi. Sesuai dengan teknik pengambilan sample pada penelitian ini menggunakan purposive sampling dengan kriteria mahasiswa yang bekerja pada Bagian Akuntansi. Maka kuesioner yang dapat digunakan dan diolah adalah sebesar 125 kuesioner.

\subsection{Karakteristik Responden}

Karakteristik responden pada penelitian ini dapat ditampilkan sebagai berikut:

Tabel.4.1 Karakteristik Responden

\begin{tabular}{l|l|r|r}
\hline Karakteristik & \multicolumn{1}{c}{ Item } & Jumlah & Persentase \\
\hline \multirow{3}{*}{ Umur } & $<25$ Tahun & 113 orang & $90.4 \%$ \\
& 25 Tahun-35 Tahun & 11 orang & $8.8 \%$ \\
\cline { 2 - 4 } & $>25$ Tahun & 1 orang & $0.8 \%$ \\
\hline \multirow{2}{*}{ Status } & Single & 118 orang & $94.4 \%$ \\
\cline { 2 - 4 } & Menikah & 7 orang & $5.6 \%$ \\
\hline \multirow{2}{*}{ Jenis Kelamin } & Laki-laki & 13 orang & $10.4 \%$ \\
\cline { 2 - 4 } & Perempuan & 112 orang & $89.6 \%$ \\
\hline \multirow{2}{*}{$\begin{array}{l}\text { Pengalaman } \\
\text { Kerja }\end{array}$} & $<5$ Tahun & 112 orang & $89.6 \%$ \\
\cline { 2 - 4 } & 5 Tahun-10 Tahun & 12 orang & $9.6 \%$ \\
\cline { 2 - 4 } Pendapatan & $>10$ Tahun & 1 orang & $0.8 \%$ \\
\hline \multirow{2}{*}{ perbulan } & Rp1.000.000 s/d Rp3.000.000 & 41 orang & $32.8 \%$ \\
\cline { 2 - 4 } & Rp3.000.000 s/d Rp6.000.000> Rp6.000.000 & 80 orang & $64 \%$ \\
\cline { 2 - 4 } & Rp. 6.000 .000 & 4 orang & $3.2 \%$ \\
\hline
\end{tabular}

Sumber: data diolah

\subsection{Uji Validitas dan Reliabilitas}

Validitas konvergen diukur berdasarkan nilai loading factor indikator-indikator yang mengukur konstruk tersebut. Validitas diskriminan dinilai dengan membandingkan akar AVE setiap konstruk dengan korelasi antar konstruk. Hartono (2011) menyatakan bahwa model mempunyai validitas diskriminan yang cukup jika akar AVE untuk setiap konstruk lebih besar daripada korelasi antara konstruk dengan konstruk lainnya dalam model. Berikut ini adalah tabel perbandingan tersebut:

Tabel.4.2. Nilai Akar AVE dan Korelasi antar Variabel Laten

\begin{tabular}{|c|c|c|c|c|c|c|c|c|c|c|}
\hline \multirow[b]{2}{*}{ Konstruk } & \multirow[b]{2}{*}{$\begin{array}{c}\text { Akar } \\
\text { AVE }\end{array}$} & \multicolumn{9}{|c|}{ Korelasi Antar Variabel } \\
\hline & & $\begin{array}{c}\text { ETIKA } \\
\text { BISNIS } \\
\text { PERUAA } \\
\text { HAAN }\end{array}$ & $\begin{array}{c}\text { KESERIU } \\
\text { SAN } \\
\text { KESALA } \\
\text { HAN }\end{array}$ & \begin{tabular}{|c} 
KOMIT \\
MEN \\
ORG
\end{tabular} & \begin{tabular}{|c} 
KONTROL \\
PERLKU \\
PERSPSIA \\
N
\end{tabular} & $\begin{array}{l}\text { NIAT } \\
\text { WBIn }\end{array}$ & \begin{tabular}{|l|} 
NIAT \\
WBeks
\end{tabular} & \begin{tabular}{|c|} 
NORMA \\
SUBJIKT \\
F
\end{tabular} & SIKAP WB & \begin{tabular}{|c} 
STATUS \\
PELKU \\
KESLHAN
\end{tabular} \\
\hline \begin{tabular}{|l|} 
ETIKA \\
BISNIS \\
PERUSAHA \\
AN \\
\end{tabular} & 0.856 & & & & & & & & & \\
\hline $\begin{array}{l}\text { KESERIUSA } \\
\mathrm{N} \\
\mathrm{KESALAHA} \\
\mathrm{N} \\
\end{array}$ & 1.000 & 0.285 & & & & & & & & \\
\hline \begin{tabular}{|l|} 
KOMITME \\
N ORG \\
\end{tabular} & 0.777 & 0.381 & 0.3 & & & & & & & \\
\hline \begin{tabular}{|l|} 
KONTRL R \\
PERLKU \\
PERSPSSAN
\end{tabular} & 0.828 & -0.086 & & -0.14 & & & & & & \\
\hline NIAT WBIn & 0.876 & 0.153 & 0.063 & 0.333 & -0.232 & & & & & \\
\hline \begin{tabular}{|l|}
$\begin{array}{l}\text { NIAT } \\
\text { WBeks }\end{array}$ \\
\end{tabular} & 1.000 & 0.093 & -0.097 & 0.079 & -0.101 & 0.154 & & & & \\
\hline \begin{tabular}{|l|l|} 
NORMA \\
SUBJKTF \\
\end{tabular} & 0.841 & 0.202 & -0.137 & 0.066 & -0.111 & 0.107 & 0.264 & & & \\
\hline SIKAP WB & 0.821 & 0.424 & 0.122 & 0.241 & -0.207 & 0.332 & 0.076 & 0.19 & & \\
\hline \begin{tabular}{|l|} 
STATUS \\
PELKU \\
KESLHAN \\
\end{tabular} & 1.000 & -0.091 & 0.264 & 0.022 & -0.033 & 0.046 & -0.016 & -0.077 & -0.004 & \\
\hline
\end{tabular}

Sumber: data diolah

Uji reliabilitas menunjukkan konsistensi suatu alat ukur/instrumen. Untuk mengukur reliabilitas digunakan Cronbach's alpha dan composite reliability. Nilai composite reliability harus lebih besar dari 0.7 , dan nilai cronbachs alpha harus di atas 0.6. Tabel berikut memperlihatkan hasil uji reliabilitas: 
Tabel.4.3. Nilai Composite Reliability dan Cronbachs alpha

\begin{tabular}{l|c|c}
\hline \multicolumn{1}{|c}{ Kontruk } & $\begin{array}{c}\text { Composite } \\
\text { Reliability }\end{array}$ & $\begin{array}{c}\text { Cronbachs } \\
\text { alpha }\end{array}$ \\
\hline $\begin{array}{l}\text { Ketika } \\
\text { Bisnis } \\
\text { Perusahaan }\end{array}$ & 0.891 & 0.831 \\
\hline $\begin{array}{l}\text { Keseriusan } \\
\text { Kesalahan }\end{array}$ & 1 & 1 \\
\hline $\begin{array}{l}\text { Komitmen } \\
\text { Organisasi }\end{array}$ & 0.859 & 0.785 \\
\hline $\begin{array}{l}\text { Kontrol } \\
\text { Perilaku } \\
\text { Persepsi }\end{array}$ & 0.867 & 0.772 \\
\hline Niat WBIn & 0.943 & 0.924 \\
\hline Niat Wbeks & 1 & 1 \\
\hline Norma Subjt & 0.906 & 0.863 \\
\hline Sikap WB & 0.892 & 0.843 \\
\hline $\begin{array}{l}\text { Status } \\
\text { Pelaku } \\
\text { Kesalahan }\end{array}$ & 1 & 1 \\
\hline
\end{tabular}

Sumber: data diolah

\subsection{Pengujian Model Struktural}

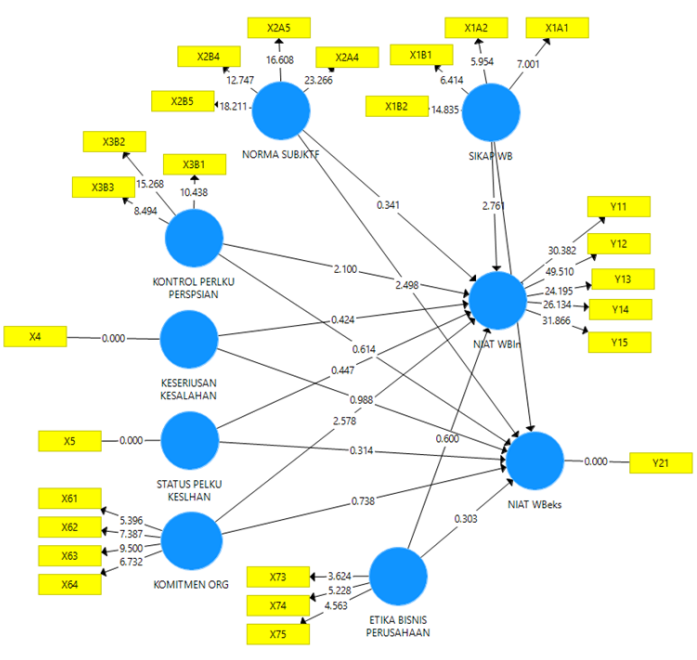

Gambar 4.1. Tampilan output model struktural

Pengujian model struktural digunakan untuk menilai signifikansi model prediksi dalam pengujian model struktural, dapat dilihat dari nilai T-statistic antara variable independen ke variable dependen dalam tabel path coefficient pada output di bawah ini:
Tabel.4.4. Koefisien Jalur pada Pengujian Model Struktural

\begin{tabular}{|c|c|c|c|c|c|}
\hline & $\begin{array}{c}\text { Original } \\
\text { Sample } \\
(0) \\
\end{array}$ & $\begin{array}{c}\text { Sample } \\
\text { Mean (M) }\end{array}$ & $\begin{array}{c}\text { Standard } \\
\text { Deviation } \\
\text { (STDEV) } \\
\end{array}$ & $\begin{array}{c}\text { TStatistics } \\
(|\mathrm{O} / \mathrm{STDEV}|) \\
\end{array}$ & P Values \\
\hline Etika Bisnis Prsh -> NIAT WBIn & -0.071 & -0.062 & 0.118 & $\overrightarrow{0.600^{\prime}}$ & 0.549 \\
\hline Etika Bisnis Prsh $>$ NIAT WBeks & 0.051 & $\overline{0.042}$ & 0.167 & $0.303^{\prime}$ & 0.762 \\
\hline Keseriusan Kesalahan $>$ NIAT WBIn & -0.042 & -0.039 & 0.098 & 0.424 & 0.672 \\
\hline Keseriusan Kesalahan -> NIAT WBeks & -0.107 & -0.097 & 0.109 & 0.988 & 0.325 \\
\hline Komitmen Org $>$ NIAT WBIn & 0.286 & $\overline{0.309}$ & 0.111 & $2,578^{\prime \prime}$ & 0.011 \\
\hline Komitmen Org -> NIAT WBeks & 0.069 & 0.077 & 0.093 & $0.738^{\prime}$ & 0.461 \\
\hline Kontrol Perilaku Perspsn -> NIAT WBIn & -0.138 & -0.144 & 0.066 & $2,100^{\prime}$ & 0.037 \\
\hline Kontrol Perilaku Perspsn -> NIAT WBeks & -0.061 & -0.057 & 0.100 & $0.614^{\prime \prime}$ & 0.540 \\
\hline Norma Subjktf $\rightarrow>$ NIAT W BIn & 0.035 & 0.044 & 0.102 & $0.341^{\prime}$ & 0.733 \\
\hline Norma Subjktf $->$ NIAT W Beks & 0.232 & 0.234 & 0.093 & $2,498^{\prime}$ & 0.013 \\
\hline Sikap WB $->$ NIAT WBIn & 0.263 & $\overline{0.252}$ & 0.095 & $2,761^{\prime}$ & 0.005 \\
\hline Sikap WB $>$ NIAT WBeks & -0.006 & -0.007 & 0.128 & 0.043 & 0.966 \\
\hline $\begin{array}{l}\text { Status Pelak Keslhn }>>\text { NIAT WBIn } \\
\end{array}$ & 0.043 & 0.033 & 0.097 & $0.447^{\circ}$ & 0.655 \\
\hline Status Pelak Keslhn $>>$ NIAT WBeks & 0.031 & $\overrightarrow{0.024}$ & 0.099 & $0.314^{\prime}$ & 0.754 \\
\hline
\end{tabular}

Sumber: data diolah

Berdasarkan nilai Beta Koefisien dan nilai T-Statistic di atas, maka hasil uji untuk masing-masing hipotesis adalah sebagai berikut ini:

Hipotesis 1a yang menyatakan sikap terhadap whistle-blowing, berpengaruh terhadap niat untuk melakukan whistle-blowing internal, berdasarkan tabel 4.4 terlihat bahwa nilai T Statistics di atas 1,96 untuk hipotesis dua ekor (two-tailed) yaitu sebesar 2.761 dan nilai $\mathrm{P}$ Values/ nilai signifikansi di bawah 5\% yaitu sebesar 0.005 maka hipotesis 1a terdukung.

Hipotesis 1b yang menyatakan sikap terhadap whistle-blowing, berpengaruh terhadap niat untuk melakukan whistle-blowing eksternal, informasi yang ditunjukkan dari tabel 4.4 terlihat bahwa nilai $\mathrm{T}$ Statistics di bawah 1, 96 yaitu sebesar 0.043 dan nilai $P$ Values/ nilai signifikansi di atas 5\% yaitu sebesar 0.966 maka hipotesis $1 \mathrm{~b}$ tidak terdukung.

Hipotesis 2a yang menyatakan norma subjektif berpengaruh terhadap niat untuk melakukan whistle-blowing internal, berdasarkan tabel 4.4 terlihat bahwa nilai T Statistics di bawah 1,96 yaitu sebesar 0.341 dan nilai P Values/ nilai signifikansi di atas 5\% yaitu sebesar 0.733 maka hipotesis 2 a tidak terdukung.

Hipotesis $2 b$ yang menyatakan norma subjektif berpengaruh terhadap niat untuk melakukan whistle-blowing eksternal, berdasarkan tabel 4.4 terlihat bahwa nilai $\mathrm{T}$ Statistics di atas 1,96 yaitu sebesar 2.498 dan nilai $\mathrm{P}$ Values/ nilai signifikansi di bawah 5\% yaitu sebesar 0.013 maka hipotesis $2 b$ terdukung.

Hipotesis 3a yang menyatakan kontrol perilaku persepsian berpengaruh terhadap niat untuk melakukan whistle-blowing internal, berdasarkan tabel 4.4 terlihat bahwa nilai T Statistics di atas 1,96 yaitu sebesar 2.100 dan nilai P Values/ nilai signifikansi di bawah 5\% yaitu sebesar 0.037 maka hipotesis 3 a terdukung.

Hipotesis $3 b$ yang menyatakan kontrol perilaku persepsian berpengaruh terhadap niat untuk melakukan whistle-blowing eksternal, berdasarkan tabel 4.4 
terlihat bahwa nilai T Statistics di bawah 1,96 yaitu sebesar 0.614 dan nilai P Values/ nilai signifikansi di atas $5 \%$ yaitu sebesar 0.540 maka hipotesis $3 \mathrm{~b}$ tidak terdukung.

Hipotesis 4a Keseriusan kesalahan, berpengaruh terhadap niat untuk melakukan whistle-blowing internal berdasarkan tabel 4.4 terlihat bahwa nilai $\mathrm{T}$ Statistics di bawah 1,96 yaitu sebesar 0.424 dan nilai $\mathrm{P}$ Values/ nilai signifikansi di atas $5 \%$ yaitu sebesar 0.672 maka hipotesis $4 \mathrm{a}$ tidak terdukung.

Hipotesis 4b Keseriusan kesalahan, berpengaruh terhadap niat untuk melakukan whistle-blowing eksternal berdasarkan tabel 4.4 terlihat bahwa nilai T Statistics di bawah 1,96 yaitu sebesar 0.988 dan nilai $\mathrm{P}$ Values/ nilai signifikansi di atas $5 \%$ yaitu sebesar 0.325 maka hipotesis $4 \mathrm{~b}$ tidak terdukung.

Hipotesis 5a Ketidak sesuaian yang dilakukan oleh atasan berpengaruh terhadap niat untuk melakukan whistle-blowing internal berdasarkan tabel 4.4 terlihat bahwa nilai $\mathrm{T}$ Statistics di bawah 1,96 yaitu sebesar 0.447 dan nilai $\mathrm{P}$ Values/ nilai signifikansi di atas 5\% yaitu sebesar 0.655 maka hipotesis 5 a tidak terdukung.

Hipotesis 5b Ketidak sesuaian yang dilakukan oleh atasan berpengaruh terhadap niat untuk melakukan whistle-blowing eksternal berdasarkan tabel 4.4 terlihat bahwa nilai $\mathrm{T}$ Statistics di bawah 1,96 yaitu sebesar 0.314 dan nilai $\mathrm{P}$ Values/ nilai signifikansi di atas 5\% yaitu sebesar 0.754 maka hipotesis $5 \mathrm{~b}$ tidak terdukung.

Hipotesis 6a Komitmen organisasi berpengaruh terhadap niat untuk melakukan whistle-blowing internal berdasarkan tabel 4.4 terlihat bahwa nilai $\mathrm{T}$ Statistics di atas 1,96 untuk hipotesis dua ekor (two-tailed) yaitu sebesar 2.578 dan nilai $\mathrm{P}$ Values/ nilai signifikansi di bawah $5 \%$ yaitu sebesar 0.011 maka hipotesis 6a terdukung.

Hipotesis $6 \mathrm{~b}$ Komitmen organisasi berpengaruh terhadap niat untuk melakukan whistle-blowing eksternal berdasarkan tabel 4.4 terlihat bahwa nilai $\mathrm{T}$ Statistics di bawah 1,96 yaitu sebesar 0.738 dan nilai $\mathrm{P}$ Values/ nilai signifikansi di atas $5 \%$ yaitu sebesar 0.461 maka hipotesis $6 \mathrm{~b}$ tidak terdukung.

Hipotesis 7a Etika bisnis perusahaan berpengaruh terhadap niat untuk melakukan whistle-blowing internal berdasarkan tabel 4.4 terlihat bahwa nilai $\mathrm{T}$ Statistics di bawah 1,96 yaitu sebesar 0.600 dan nilai $P$ Values/ nilai signifikansi di atas $5 \%$ yaitu sebesar 0.549 maka hipotesis 7 a tidak terdukung.

Hipotesis 7b Etika bisnis perusahaan berpengaruh terhadap niat untuk melakukan whistle-blowing eksternal berdasarkan tabel 4.4 terlihat bahwa nilai T Statistics di bawah 1,96 yaitu sebesar 0.303 dan nilai $\mathrm{P}$ Values/ nilai signifikansi di atas $5 \%$ yaitu sebesar 0.762 maka hipotesis $7 \mathrm{~b}$ tidak terdukung.

\section{Kesimpulan}

Berikut ini adalah kesimpulan penelitian ini:

1. Terdapat pengaruh sikap terhadap whistle-blowing terhadap niat untuk melakukan whistle-blowing internal.

2. Tidak terdapat pengaruh sikap terhadap whistle-blowing terhadap niat untuk melakukan whistle-blowing eksternal.

3. Tidak terdapat pengaruh norma subjektif terhadap terhadap niat untuk melakukan whistle-blowing internal.

4. Terdapat pengaruh norma subjektif terhadap niat untuk melakukan whistle-blowing eksternal.

5. Terdapat pengaruh kontrol perilaku persepsian terhadap niat untuk melakukan whistle-blowing internal.

6. Tidak terdapat pengaruh kontrol perilaku persepsian terhadap niat untuk melakukan whistle-blowing eksternal.

7. Tidak terdapat pengaruh keseriusan kesalahan, terhadap niat untuk melakukan whistle-blowing internal.

8. Tidak terdapat pengaruh keseriusan kesalahan, terhadap niat untuk melakukan whistle-blowing eksternal.

9. Tidak terdapat pengaruh ketidak sesuaian yang dilakukan oleh atasan terhadap niat untuk melakukan whistle-blowing internal.

10. Tidak terdapat pengaruh ketidak sesuaian yang dilakukan oleh atasan terhadap niat untuk melakukan whistle-blowing eksternal.

11. Terdapat pengaruh komitmen organisasi terhadap niat untuk melakukan whistle-blowing internal.

12. Tidak terdapat berpengaruh komitmen organisasi terhadap niat untuk melakukan whistle-blowing eksternal.

13. Tidak terdapat pengaruh etika bisnis perusahaan terhadap niat untuk melakukan whistle-blowing internal.

14. Tidak terdapat pengaruh etika bisnis perusahaan terhadap niat untuk melakukan whistle-blowing eksternal

\section{Saran dan Keterbatasan}

$\mathrm{R}$ square di dalam penelitian ini rendah,berarti masih terdapat banyak faktor yang mempengaruhi niat untuk melakukan whistle-blowing. Penelitian selanjutnya dapat memasukkan faktor-faktor lain yang berkemungkinan berpengaruh terhadap niat untuk melakukan whistle-blowing. Sampel penelitian selanjutnya dapat diperluas, sampel penelitian ini hanya terbatas pada karyawan Bagian Akuntansi yang menempuh pendidikan kelas karyawan di Politeknik Negeri Batam sehingga generalisasi penelitian menjadi terbatas. 


\section{Daftar Pustaka}

[1] http://www.transparency.org, diakses April 2016.

[2] http://Haluankepri.com/batam/85495-tengkatakan -pt-emr-rugi-rp36-m.html. Diakses Juni 2016.

[3] Alleyne, P., Marshall. D.W., Arthur, R. (2013). Exploring Factors Influencing Whistle-Blowing Intentions among Accountants in Barbados. Journal of Eastern Caribbean Studies. Vol.38, No.1 dan 2., March/June, pp.35-62.

[4] Hartono, J. (2008). Sistem Informasi Keperilakuan Edisi Revisi. Yogyakarta: Andipublisher.

[5] David, Fred.R. (2011). Strategic Management (Concepts and Cases) thirteenth edition. Prentice Hall: United States of America.

[6] Luthans, F. (2006). Perilaku organisasi (vol 10). Yogyakarta: Andi.

[7] Winardi, D.,R. (2013). The Influence of Individual and Situational Factors on Lower Level Civil Servants Whistle-Blowing Intention in Indonesia. Journal of Indonesian Economy and Business. Volume 28, Number 3, 2013, 361-367.

[8] Alleyne, Philmore. (2016). The influence of organisational commitment and corporate ethical values on non-public accountants' whistle-blowing intentions in Barbados. Journal of Applied Accounting Research, Vol. 17 Iss 2 pp.

[9] Gudono dan Latan, H. (2013). Structural Equation Modeling. Yogyakarta: BPFE Yogyakarta

[10]Sholihin, M \& Ratmono, D. Analisis SEM-PLS dengan WarpPLS 3.0 Untuk Hubungan Nonlinier Dalam Penelitian Sosial dan Bisnis. 1St Published. 